\title{
Effect of Diversification Strategy, Directors Compensation, Managerial Ownership and Company Sizes on Company Performance
} Hendronoto Hadi Wibowo ${ }^{1 *}$, Lodovicus Lasdi ${ }^{2 *}$

\author{
1,2 Widya Mandala Catholic University of Surabaya. \\ *Corresponding authors.Email: hendronoto30@gmail.com. lodovicus@ukwms.ac.id.
}

\begin{abstract}
Diversification strategy is chosen by managers of companies to develop their business that can improve the performance of a company. One way to evaluate the performance of company management is by give compensation. Ownership in the structure capital in company there are several kinds one sample of the managerial ownership is the ownership of shares owned by managers and employees. The size of the company can see the total assets owned by the company used to generate profits. Performance is a way to measure the level of success of a company from management activities whose information is obtained from the company's financial statements. The object of research is manufacturing sector companies listed on the Indonesia Stock Exchange (IDX) in 20152018, The results in the research in that the strategy of diversification, compensation of director's and managerial ownership is not given affect to be able to the performance of the company, while the results of the size of the company influences the company's performance.
\end{abstract}

Keywords: Diversification Strategy, Board of Directors Compensation, Managerial Ownership, and company size

\section{INTRODUCTION}

The era of globalization now, the level of need for the use of technology is very high. The use of this technology is supported by a very adequate internet network so that communication in trade between countries is very easy and triggers the ASEAN Economic Community (AEC). One of the impacts of the AEC is that every company competes to become a excellect company. In addition to the impact caused by the AEC, company competition is also getting tougher due to the industrial revolution 4.0.

BBC.Com (2018), revolution 4.0 is a source of revolution where technology development is very fast and this technology can help companies expand market share easily. In the development and growth of companies in Indonesia, which is increasingly rapid, which causes each company to carry out operational activities will implement various strategies to survive and improve company performance.
Diversification strategy is a geographic expansion of the business as well as market share or making the products of a company into various types which are expected to improve company performance (Harto, 2005). Good or bad in company performance can be supported management in the company to choosed strategy for achieved purposed company, many strategies to choosed from management. Diversafication strategy is one of several corporate strategies. Reasearch on Lukman (2014) that the diversification strategy carried out by the company has a improve effect on company performance, and Azis, Hermawan, dan Rossieta. (2016) also that diversification strategies can reduce company performance.

Implementing a diversification strategy in improving company performance, motivating company managers is another method to improve company performance in achieving company goals by providing compensation for directors. Company can used to motivate management to improve company performance, compensation for directors 
can also solve conflict problems that often occur in companies

The research Theeravanich (2013) which examines the compensation of directors, concludes that the compensation for directors has no positive effect on company performance. Meanwhile, research of the Azis, et all (2016) stated that compensation for directors be affected positive for company performance.

Managerial ownership is the one ownership structures in the company showing that the company is also owned by the company management and even by employees. Therefore, managerial ownership indicates that there is a share of share ownership from the management, but management remains an active party in various company operational activities (Wahyudi and Pawestri, 2006). With managerial ownership, it will have an indirect impact on the company in an effort to align the position of management and company employees with shareholders. The research at Short and Keasey (1999) who have examined the effect of managerial ownership on managerial performance, it is concluded that ownership has a positive impact on company performance.

Firm size as the last independent variable in this study is due to the inconsistency of research results in several studies that have been conducted. The Reasearch of Kurniasari (2014), to find out the size company can be seen of the total assets if value of the assets is getting bigger the more the company can be diversified to improve company performance, this is because large companies have large enough funding. The object of this study consists of manufacturing companies listed on the Indonesian stock exchange for the 2015-2018 period.

\section{LITERATURE REVIEW}

\subsection{Agency Theory}

This theory of a relationship involving two parties, the first party is called the principal party or also known as the owner, which consists of one or more people who make a relationship with two parties which are usually called agents or management, the principal party has an obligation. provide funds for operational activities while the agent manages the company to achieve company goals.
Jensen and Meckling (1976), agency conflict has two relationships, the first is conflict caused by the manager and the shareholders, the manager acts in the interests of the manager by adding facilities with the aim of the manager's own interests that will be obtained from the company because the provision of such facilities will be at the expense of the shareholder or the principal.

\subsection{Diversification Strategy}

Strategy is a company way of achieved purpose vision and mission company, company objectives where the company can offer goods and services according to the needs of consumers (Rangkuti, 2014: 3)

There are two types of diversification strategies, related diversification strategies and unrelated diversification strategies. When the company switches to new business lines that are still related to the company's operational activities, while companies that implement a strategy in which the company's value chain is not in accordance with operational activities or what is usually called a diversified strategy activity is not related, the company will do things by acquiring other companies that have high opportunities for sustainability but with the problem of lack of funding sources in carrying out operational activities (David, 2015:133)

\subsection{Compensation for The Board of Directors}

If management in the company can be to worked together determining the strategies undertaken by the company in achieving company goals and solving various problems that occur such as agency conflicts in a company. In providing compensation is a reciprocal action on the performance of the board of directors during their function and is a sense of concern from the owner to the board of directors (Jensen and Meckling, 1976). In addition to being used to motivate management to improve company performance, board of directors compensation is used as a way to solve conflict problems that often occur in companies. Chen (2013), if the compensation for directors given is too large compared to the duties and responsibilities given to the directors, then the compensation will disturb the performance of a company. 


\subsection{Corporate Governance Mechanisms}

Corporate governance is a system that directs and controls the relationship between investors, managers, creditors, government, employees in fulfilling the rights and obligations of these parties. In addition, the reason for one of the impacts of implementing corporate governance is that it can overcome the problem of agency conflicts in a company by overcoming monitoring and assessing the performance of a company and also controlling the behavior of managers who are concerned with the interests of managers. (Sutedi, 2012: 1)

In implementing corporate governance, the objective is to be able to motivate managers to run according to the wishes of investors and to reduce agency problems that occur (Hamdani, 2016: 31). In this study, the corporate governance mechanism will use the managerial ownership factor, because managerial ownership is expected to affect the operational activities of the company which will affect the company's performance in achieving one of the company's many goals, namely to maximize the company's value.

\subsection{Company Performance}

Company performance is the level of success of management in managing the company to achieve success, company performance is measured using financial analysis tools so that can be measure whether management can manage the company well in achieving company goals (Rani, 2015).

In determining the company's performance, it is said to be good, it requires a complete and accurate company financial report, the income statement in the financial report can have an impact in the form of evaluating the performance of each component in the company's operational activities besides the performance also regarding the profitability carried out by the operational segment

Brigham and Houston (2014: 133) company financial statements are used to evaluate company performance in terms of finance. In measuring the effectiveness of financial ratios, financial ratios include liquidity ratios, profitability ratios, and growth ratios. Brigham and Houston (2014: 134).

ROA is a measure of the success of the company in obtaining profits by utilizing assets owned by the company, ROA is the most important ratio among other profitability ratios for the company because of how managers solve problems and earn profits with available company assets, if the higher the ROA of a company it can be said that The company's performance has increased

\subsection{The Effect of Diversification Strategy on Company Performance}

Strategy is a company way of achieving goals, company objectives where the company can offer goods and services according to the needs of consumers (Rangkuti, 2014: 3). Along with the growing pace of the company in the process of making various types of products, it has an impact on consumers, where consumers will quickly feel bored with old products. The hypothesis that occurs in this study:

H1: Diversification strategy be affected positive on Company performance

\subsection{Effect of Compensation of Directors on Company Performance.}

Compensation for directors is a reciprocal between the company and the manager, besides that it can also be used as a communication tool for evaluating the manager's performance in improving the company's performance and value. Apart from being used to motivate management to improve company performance, compensation for directors can also solve conflict problems that often occur in companies.

The conflict is about the different views and interests between the stakeholders and the company management. The results of research by Azis et al (2016) in the compensation for directors has a positive impact on company performance. This is because the effect of compensation can affect management control in company performance. Based on the elaboration, the hypothesis that occurs in this study.

H2: The Compensation of Directors be affected positive on Company Performance. 


\subsection{Effect of Managerial Ownership on Company Performance}

Tjeleni (2013) explains that managerial ownership is a condition in which management plays a role as a company manager and also as a share owner because management owns shares in the company. The function and role of management to manage the company is the responsibility of delegation of authority given by the owner of the company. The Reasearch Short and Keasey (1999) an Chen and $\mathrm{Yu}$ (2011) have examined the impact of managerial ownership on company performance, Them conclude that ownership managerial has a affected positive on company performance.

H3: Managerial Ownership be affected positive on Company Performance

\subsection{The Influence of Company Size on Company Performance}

Reasearch of Kurniasari (2014), to find out the size company can be seen of the total assets if value of the assets is getting bigger the more the company can be diversified to improve company performance. This is because large companies have large enough funding. In calculating the size of the company, one method can be used, namely the logarithm of total assets owned by the company. Based on the elaboration, the hypothesis that occurs in this study.

H4: Company size be affected positive effect on company performance

\section{RESEARCH METHOD}

This research is a quantitative type of research in which this study to examine the effect of diversification strategies, director's compensation, ownership in managerial and size in the company performance. The object of this study will use manufacturing companies that have been listed on the IDX in the 2015-2018.

Company performance is the dependent variable in this study. Company performance is the level of success of management in managing the company to achieve success, company performance is measured using financial analysis tools so that it can be measured whether management can manage the company well in achieving company goals (Rani, 2015). ROA is a measure of the company's success in obtaining profits by utilizing assets owned by the company, according to Brigham and Houston (2014: 148), if the ROA value approaches 1 , the more efficient the company's operations will be (Kurniasari, 2014).

$$
\mathrm{ROA}=\frac{\text { Net income after } \text { tax }}{\text { Total Asset }}
$$

Diversification strategy is one of the strategies used by companies in expanding their business by carrying out a strategic business unit (SBU) or a subsidiary of Wisnuwardhana and Diyanti (2015). This research will use the measurement or level of company diversification by using the Herfindahl index which is derived from the sales of the company's business segments, the index is generated based on the square of sales of each operational segment which will be divided with company's total sales. If the results of the index are close to number 1 , it can be said that the company is increasingly focused on one product line, whereas if the index results are close to number 0 , the company is said to be diversifying its products. Villalonga (2004) In calculating the Herfindahl index it can be formulated as follows:

$$
\mathrm{H}=\sum_{i=1}^{N}
$$

Information:

H: Herfindahl Index

Si: The proportion of sales per segment of the company's total sales.

Compensation for directors is one of the management control mechanisms where the compensation for directors is expected to motivate management to improve company performance to achieve certain company goals. Apart from being used to motivate management to improve company performance, compensation for directors can also solve conflict problems that often occur in companies. The conflict is about the different views and interests between the stakeholders and the company management. Compensation for directors is a reciprocal between the company and the manager, besides that it can also be used as a communication tool for evaluating the manager's performance in improving the company's performance and value. In assessing the 
compensation of the Directors (KD), it can be calculated by the formula:

$$
\mathrm{KD}=\mathrm{Ln} \text { (Directors' compensation) }
$$

Managerial ownership in which the variable strengthens the independent variable in terms of affecting the dependent variable. Managerial ownership is part of the shareholder of management but is an active party in various company operational activities (Wahyudi and Pawestri, 2006). Sukrini (2012), managerial ownership is share ownership in a company where the ownership is owned by company management and even employees. To find out the percentage of active management, it can be measured by adding up the percentage of shares owned by active management. (Supriyadi, 2017)

$$
\mathrm{KM}=\frac{\text { Total of shares owned managerial }}{\text { Total of common shares }}
$$

Reasearch of Kurniasari (2014), to find out the size company can be seen of the total assets if value of the assets is getting bigger the more the company can be diversified to improve company performance. This is because large companies have large enough funding. In calculating the size of the company, one method can be used, namely the logarithm of total assets owned by the company (Wulandari and Septiani 2017)

$$
\text { Firm Sizes }=\text { Ln }(\text { Total Asset })
$$

\section{RESULT AND DISCUSSION}

In the descriptive statistics, this study explains that the dependent and independent variables used are: return on assets, diversification strategies, compensation for directors, managerial ownership and company size. Table 1 will explain the minimum value, maximum value, average value, and standard deviation of each variable.

\begin{tabular}{|l|c|r|r|}
\hline & N & \multicolumn{1}{c|}{ Minimum } & Maksmimum \\
\hline ROA & 202 & $-1,1011$ & 0,2273 \\
\hline DIV & 202 & 0,4711 & 1,0000 \\
\hline KD & 202 & 19,8268 & 26,3688 \\
\hline KM & 202 & 0,0000 & 0,68275 \\
\hline SIZE & 202 & 24,5247 & 32,2010 \\
\hline
\end{tabular}

\begin{tabular}{|l|l|l|l|}
\hline $\begin{array}{l}\text { Valid N } \\
\text { (listwise) }\end{array}$ & 202 & & \\
\hline
\end{tabular}

\begin{tabular}{|l|r|r|}
\hline & \multicolumn{1}{|c|}{ Average } & Standard Deviation \\
\hline ROA & 0,0403 & 0,0604 \\
\hline DIV & 0,9455 & 0,1102 \\
\hline KD & 23,9778 & 1,3341 \\
\hline KM & 0,0646 & 0,1211 \\
\hline SIZE & 28,2965 & 1,5084 \\
\hline $\begin{array}{l}\text { Valid N } \\
\text { (listwise }\end{array}$ & & \\
\hline
\end{tabular}

Determination Coefficient Test (R2) The coefficient of determination test results can be seen in Table 2

\begin{tabular}{|l|l|l|l|}
\hline $\mathrm{R}$ & $\mathrm{R}$ Square & Adjusted $R$ & Std. Error of the \\
\hline 0.416 & 0.173 & 0.156 & 0.0556 \\
\hline
\end{tabular}

The results of the coefficient of determination in table 2 show that the adjusted $\mathrm{R}$ square is 0.156 , that the independent variables (diversification strategy, board of directors compensation, managerial ownership, and company size) can affect the dependent variable (company performance) of 0.156 or $15.6 \%$, so that $84.4 \%$ is explained by other variables not in this study.

\begin{tabular}{|l|l|}
\hline $\mathrm{F}$ & Signfikansi \\
\hline 10,288 & 0,000 \\
\hline
\end{tabular}

The results of the F statistical test in table 3 show a significance value of $\mathrm{F}$ of 0.000 . This shows that the regression model in testing the hypothesis of the effect of diversification strategies, directors compensation, managerial ownership, company size on company performance is a model that is fit or feasible to use because it has a significance value of $\mathrm{F}$ less than 0.05 . 


$$
\begin{gathered}
\mathrm{KP}=\alpha+\beta 1 \mathrm{DIV}+\beta 2 \mathrm{KD}+\beta 3 \mathrm{KM}+\beta 4 \mathrm{SIZE}+\mathrm{e} \\
\mathrm{KP}=-0,374+-0,053 \mathrm{DIV}+0,003 \mathrm{KD}+0,06 \mathrm{KM}+ \\
0,014 \mathrm{SIZE}
\end{gathered}
$$

The coefficient of the research diversification strategy (DU) independent variable has a negative value of -0.053 , so it can be concluded that the diversification strategy will reduce ROA by 0.053 and also this strategy is positive with sig.t, namely 0.232 but $0.232>0.05$.

The coefficient of directors' compensation $(\mathrm{KD})$ is 0.003 , so it can be concluded that if the compensation for the directors increases, it will also increase the value of the company's ROA by 0.003 and the compensation for the directors is also positive with sig.t, namely 0.490 but $0.490>0.05$.

The coefficient of managerial ownership (KM) in this study shows a positive value of 0.06 , so it can be concluded that if managerial ownership increases, it will also have an impact on ROA which increases by 0.06 and managerial ownership is also positive with sig.t, which is 0.076 however $0.076>0.05$

The coefficient of company size (SIZE) in this study also shows a positive value, which is equal to 0.014 , so it can be concluded that if there is an increase in the value of the company size it will increase the ROA value by 0.014 and also have a positive sign with sig.t, which is 0.001 and $0.001<$ 0,5 .

Based on research analysis, it is concluded that the first hypothesis is not accepted, because diversification strategy do not have an impact on company performance, if the diversification strategy is not supported by the efficient and effective allocation of company resources.

That the second hypothesis in research of is no accepted, In the second hypothesis to provide evidence company performance can't be influenced by role of the directors' compensation. Due to the provision of compensation, both large and small, can only affect the motivation of the directors on a fairly small scale.

Based on the results of the research analysis, it is concluded that the third hypothesis is rejected, which proves that the role of managers in having share ownership in the company is proven to have no effect on company performance. This shows that managerial ownership in a company has not shown that managerial ownership can affect company performance. This is because the percentage of managerial ownership does not have a high enough level of materiality with other stock ownership.

The fourth hypothesis is accepted, that the size of the company will affect the performance of the company. This shows that company size can affect company performance because the size of the company will affect the company's performance.

The research limitedness, in the study there are four independent variables are diversification strategies, director's compensation, managerial ownership, and company size with these variables still unable to influence the dependent variable. The research sample only uses manufacturing companies with several criteria so that the manufacturing companies cannot be comprehensive. In the research sample only 4 years period so it cannot show the of diversification strategies in improving company performance.

\section{CONCLUSIONS}

The conclusions and limitations of the study, the researchers provided suggestions for further research. Expected to add measurements to the independent variables of diversification strategies such as cost leadership and differentiation (Azis, et al, 2016). Researchers are expected to add manufacturing companies with other companies in the research object. Researchers are expected to add the length of the period in the research sample so that they can see the trend of diversification strategies on company performance.

\section{REFERENCES}

[1]. Azis, A. D., A. A. Hermawan, dan H. Rossieta. (2016). Dampak Strategi Diversifikasi dan Kompensasi Direksi terhadap Kinerja Perusahaan. Simposium Nasional Akuntansi XIX: Lampung, Agustus: 1-19.

[2]. BBC.Com (2018). Peta jalan ekonomi digital Indonesia: Jokowi tampik ratusan juta pengangguran baru. Didapat dari https://www.bbc.com/indonesia/indonesia -43637255\#orb-banner, 06 Agustus 2019 , pukul 21.41 WIB 
[3]. Brigham dan Houston. (2014). Manajemen Keuangan Buku II. Jakarta: Penerbit Erlangga

[4]. Chen, Shun-Yu dan Li-Ju Chen, (2011), Capital structure determinant: An empirical study in Taiwan, African Journal of Business Management Vol. 5(27). 10974-10983.

[5]. Chen, H. W. (2013). Family Ties, Board Compensation, and Firm Performance. Journal of Multinational Financial Management, 23, 255-271.

[6]. Chriselly, F., dan Mulyani. (2016). Kepemilikan Manajerial sebagai Pemoderasi Pengaruh Strategi Diversifikasi terhadap Kinerja Perusahaan. Institut Bisnis dan Informatika Kwik Kian Gie Jurnal, 5(2), 169-184.

[7]. David, F. R., (2015). Manajemen Strategik: Suatu Pendekatan Keunggulan Bersaing (edisi ke-15). Jakarta: Salemba Empat.

[8]. Govindarajan, V.A. (1988). Contingency Approach to Strategy Impelementation at the Business-Unit Level: Integrating Adminstrative Mechanisms with Strategy. Academy of Management Journal, 828855.

[9]. Hamdani. (2016). Good Corporate Governance. Jakarta: Salemba Empat

[10]. Harto, P. (2005). Kebijakan Diversifikasi Perusahaan dan Pengaruhnya terhadap Kinerja: Studi Empiris pada Perusahaan Publik di Indonesia. Simposium Nasional Akuntansi VII:Solo,297-307

[11]. Hit, M. A., Ireland, R. D., \& Hoskisson, R. E. (2012). Strategic Management: Competitiveness and Globalization (Concepts and Cases), (Edisi ke 11).USA: Stamford.

[12]. Jensen, M. C., dan W. H. Meckling. (1976). Theory of the Firm: Managerial Behavior, Agency Costs and Ownership
Structure. Journal of Financial Economics, 3(4), 305-360.

[13]. Kurniasari, A. E. (2014). Pengaruh Diversifikasi Usaha terhadap Kinerja Perusahaan yang Dimoderasi oleh Kepemilikan Manajerial. Universitas Dian Nuswantoro Jurnal, Hal. 1-9

[14]. Rangkuti, Freddy. 2014. Analisis SWOT: Teknik Membedah Kasus Bisnis. Jakarta. PT Gramedia Pustaka Utama

[15]. Septiani, A., dan Wulandari, A.N.R. (2017). Pengaruh ukuran perusahaan, profitabilitas, dan laverage terhadap sustainability disclosure. Diponegoro Journal Of Accounting, 6 (4), 1-8.

[16]. Short, H. and K. Keasey. 1999. Managerial Ownership and the Performance of Firms: Evidence from the UK. Journal of Corporate Finance, 5. 79101.

[17]. Siallagan, H., \& Machfoedz, M. (2006). Mekanisme Corporate Governance Kualitas Laba dan Nilai Perusahaan. (61), 23-26.

[18]. Supriyadi, T. (2017). Pengaruh Mekanisme Good Corporate Governance terhadap Ketepatan Waktu Penyampaian Laporan Keuangan. (Skripsi, Program Studi Akuntansi Fakultas Ekonomi dan Bisnis Universitas Pasundan Bandung, Bandung, Indonesia). Didapat dari http://repository.unpas.ac.id/27333/.

[19]. Sutedi, A. (2012). Good Corporate Governance. Jakarta: Sinar Grafika

[20]. Solomon, J. (2013). Corporate governance and accountability (edisi ke4). New Jersey: John Wiley dan Sons Ltd

[21]. Theeravanich, A. (2013). Director Compensation in Emerging Markets: A Case Study of Thailand. Journal of Economics and Business, 70, 71-91.

[22]. Wahyudi, U., dan H. P. Pawestri. 2006. Implikasi Struktur Kepemilikan Terhadap Nilai Perusahaan: dengan Keputusan 
Keuangan sebagai Variabel Intervening. Simposium Nasional Akuntansi IX: Padang:

[23]. Wisnuwardhana, A., dan Diyanty, V. (2015). Pengaruh Strategi Diversifikasi Terhadap Kinerja Perusahaan Dengan Moderasi Efektivitas Pengawasan Dewan Komisaris. Simposium Nasional Akuntansi XVIII: Medan. 